\title{
Development of Plant Pigment Extraction Machine
}

\author{
Asha Saturday", Bolariwa Gabriel O, Adeniji Adeyemi
}

National Engineering Design Development Institute (NEDDI), PMB 5082, Nnewi, Anambra State, Nigeria

DOI: $10.36347 /$ sjet.2020.v08i10.001

| Received: 29.09.2020 | Accepted: 13.10.2020 | Published: 26.10.2020

*Corresponding author: Asha Saturday

Abstract

Africans and the rest of the world have started embracing the use of herbal products. The need to develop machines for indigenous fabrication that meet the standard for acceptability in terms of hygiene and engineering standard necessitated this concept of using steam to extract the pigment from back of trees and leaves especially roselle (Hibiscus sabdariffa L) (red variety) popularly called zobo in Nigeria culled from zoborodo (Hausa language).The red pigment can be extracted through this machine. Reduction in material handling and commercial production is favored with this machine. It comprises the heating section, water section and the herbal material section which lead to the condenser and the mixer where other ingredients are introduced. It requires $2030038.8 \mathrm{kj}$ as an ideal heat to evaporate the water for extraction using electricity in one hour .Materials used are corrosion resistant materials like stainless steel and plastic.

Keywords: Reduced material handling, Vaporization, Pigment extraction, Herbal machine.

Copyright $\odot 2020$ The Author(s): This is an open-access article distributed under the terms of the Creative Commons Attribution 4.0 International License (CC BY-NC 4.0) which permits unrestricted use, distribution, and reproduction in any medium for non-commercial use provided the original author and source are credited.

\section{INTRODUCTION}

Increase in demand of herbal products in Nigeria and other parts of Sub Sahara region has necessitated the use of local machines for cost reduction and IGR generation. The extraction machine for pigment is developed to reduce handling in order to avoid contamination. Zobo drinks are gaining ground in Nigeria and this machine can enhance the commercialization of this drink. J. C. Osueke and F.N. Ehirim [1] research revealed that zobo has lower in titrable acidity, sodium and phosphorus contents but was higher in protein, ash, total soluble solids and vitamin $\mathrm{C}$ contents than the selected soft drinks. Sensory evaluation result showed that consumers rated the carbonated zobo drink higher than the soft drinks and the non-carbonated zobo. Zobo drink (Sorrel, zoborodo) as locally it is called is a local beverage made from the reddish purple, acid-succulent calyces of the flower Hibiscus Sabdariffa. This flower is highly cultivated in the northern part of Nigeria probably because of the climate. There is paucity of information on the nutritional value of zobo drink, as earlier studies were concentrated on the characteristics of the plant and its seed as well as the evaluation of its medicinal value $[2,3]$. This is a rich drink we must embrace because it is indigenous since most of the non-alcoholic beverages consumed in Nigeria come from foreign non -African countries from where they are shipped in to Nigeria as concentrates. Our major markets are flooded with various brands of soft drinks and the production plants are not sited in Africa, our benefits as a people are consumption and trade. Nigeria is endowed with local beverages 'kunu', 'suya' milk etc not only to cater for her citizen, but surplus enough for export.

\section{Motivation}

This work is motivated by the increase in awareness of herbal products. The use zobo drinks is prevalent in Nigeria hence the development of this machine for fabrication will encourage commercialization of these herbal products and local beverage like zobo.

\section{Scope}

The determination of energy requirement, reduction in material handling design consideration and, material selection are considered. The CAD, (Computer Aided Design) and CAE (Computer Aided Engineering) software solid works 2016 is used for the development of the model of the extraction machine.

\section{Aims and objectives}

Design and development of plant pigment extraction machine is the focus of this work.

To achieve this aim, specific objectives have to be met.

I. Detailed research of extraction processes and zobo 
II. Determination of some basic parameters of the machine

III. CAD and CAE design of the machine model

\section{Design methodology}

The concept starts from the sizing of the water chamber and the heat required to boil off the water, sizing the heat exchanger and the analysis of the system as well as the model for the system using CAE and FEA software-SOLIDWORKS 2016.

\section{Design Consideration}

The considerations for this work are
a. Material selection
b. Hygiene
c. Corrosion
d. Weldability
e. Availability.

\section{Material selection}

Materials are selected on the basis of availability and local content initiative. The duty of the machine under consideration guarantees the consideration for corrosion resistant material. Of course, thermal conductivity is part of the factors, hence stainless steel is selected.

\section{Heat Requirement}

The heat requirement is considered as the a major factor in this work because it is the source of the system because of $\mathrm{CO} 2$ and other gaseous products emission ,the world is in dire need to reduce $\mathrm{CO} 2$ drastically. Thus, electrical energy that will be converted to heat energy is considered. The energy consumption per hour needs to be known so that production rate and all other cost can be determined and projected.

\section{Volume of the Water Chamber}

The profile of the chamber is cylindrical

Volume of a Cylinder V

$\mathrm{V}=\pi \mathrm{r}^{2} \mathrm{~h} \quad 1$

Internal diameter ID of the cylinder

ID $=0.5 \mathrm{~m}$

$\mathrm{r}=\frac{\mathrm{ID}}{2} \quad 2$

$r=0.25$

Height $\mathrm{h}=0.405$

$\mathrm{V}=0.0796 \mathrm{~m}^{3}$

$\rho=\frac{m_{w}}{V_{w}}$

$\mathrm{m}_{\mathrm{w}}=\rho \mathrm{V}_{\mathrm{w}}$

$\rho=$ density of water $=1000 \mathrm{~kg} \mathrm{~m}^{\wedge}-3$

$\mathrm{m}_{\mathrm{w}}=796 \mathrm{~kg}$
Hence, the total useful heat requirement per hour is determined as

$\mathrm{Q}_{\text {WTоTAL }}=\mathrm{M}_{\mathrm{W}} \mathrm{C}_{\mathrm{W}}(\Delta \mathrm{T})+\mathrm{M}_{\mathrm{W}} \mathrm{L}_{\mathrm{W}}(3)$

This comprises the heat required to raise the temperature of water to $100 \mathrm{c}$ and heat of vapourization Hence

$\Delta \mathrm{T}=$ temperature difference between initial temperature of water and the boiling point

\section{Assumptions}

The following assumptions are made

i. The water is pure

ii. The initial water temperature is assumed to be ambient temperature of the surrounding.

$$
\begin{aligned}
& \Delta \mathrm{T}=100-30=70 \\
& \mathrm{C}_{\mathrm{W}}=4.19 \mathrm{kj} / \mathrm{kg} / \mathrm{C}, \mathrm{L}_{\mathrm{W}}=2257 \mathrm{~kg} / \mathrm{kg} / \\
& \mathrm{c} \text { at } 100, \mathrm{~m}_{\mathrm{W}}=796 \mathrm{~kg} \\
& \mathrm{Q}_{\text {TOTAQL }}=796 \times 4.19 \times 70+796 \times 2257 \\
& \mathrm{Q}_{\text {TOTAQL }}=233466.8+1796572=2030038.8 \text { kjoules } \\
& \mathrm{Q}_{\text {WTOTAQL }}=2030038.8 \mathrm{kj}
\end{aligned}
$$

This is the heated required to evaporate the water content in the water in every one hour

Using heating filament, the heaters ratings and numbers can be determined as given

From the law of conservation of energy

$\mathrm{Q}_{\text {TOTAQL }}$ Heat energy $=$ Electrical Energy

$\mathrm{Q}_{\mathrm{TOTAQL}}=$ Vit 5

The energy per second

energy per second $=\frac{2030038.8}{3600}=264 \mathrm{kj}$

vi $=264$

Assuming a current of 6amps the voltage required $\mathrm{v}=\frac{264}{6}=44 \mathrm{volts}$

\section{Numbers of Filament}

Assuming 30kw rating of heating filament, the numbers of filaments required are calculated number of filament $=\frac{\text { energy to be consumed }}{\text { energy rating per filament }} \quad 6$ number of filament $=\frac{264}{30}=8.8 \approx 9$ filamnts

Heat absorption by the leaves

Heat absorbed by the leaves at $30 \mathrm{C}$ is equal to the latent heat of vapourization

Assuming no heat lost

$\mathrm{Q}_{\mathrm{zTOTAL}}=\mathrm{M}_{\mathrm{W}} \mathrm{L}_{\mathrm{W}} \quad 7$
$\mathrm{Q}_{\mathrm{zfTOTAL}}=\mathrm{M}_{\mathrm{z}} \mathrm{C}_{\mathrm{z}}(\Delta \mathrm{T}) \quad 8$
$\mathrm{M}_{\mathrm{z}} \mathrm{C}_{\mathrm{z}}(\Delta \mathrm{T})=\mathrm{M}_{\mathrm{W}} \mathrm{L}_{\mathrm{W}}$

Assuming a temperature of $120 \mathrm{C}$, the heat capacity is determined

$$
\begin{aligned}
\mathrm{H}_{\mathrm{z}} & =\mathrm{M}_{\mathrm{W}} \mathrm{L}_{\mathrm{W}} / \Delta \mathrm{T} \\
\mathrm{H}_{\mathrm{z}} & =1796572 / 90 \\
\mathrm{H}_{\mathrm{z}} & =19961.1 \mathrm{~kg} / \mathrm{kg} / \mathrm{c}
\end{aligned}
$$


This is the heat capacity at $120 \mathrm{C}$

From this work only useful heat is calculated, heat loss by conduction, and infiltration are not calculated but the assumptions are made base on ideal situation. For example the volume of the heating chamber assumed in this work on a normal senario only a fraction will be filled with water hence the selection and heat calculation is still in safer condition for fast vapour generation

\section{Heat Exchangers}

Condensers are vital components that constitute most experimental works in the secondary, tertiary, pharmaceutical, research and water distillers and oil and gas industries. Condensers become inevitable for change of state of constituents from gaseous state to liquid. For effective material balance, performance and cooling (thermal) efficiency of a condenser become necessary for total recovering of the distillates to avoid material lost via gaseous escape. S.V. Patankar, D.B. Spalding [4], F.P Incropera, and D. $P$ De Witt [5]. Experimental works and other vital operations related to distillation can be achievable with a high efficient and performance condenser. Various condensers have been fabricated in the course of achieving effective cooling to avoid material lost via gaseous escape.

\section{Factors That Affect Cooling Efficiency}

Cooling processes become vital in material recovering and purification. Mixtures separated by distillation using boiling points as functions for separation are recovered in their pure undiluted state with an effective cooling media. JR Welty, CE Wicks, RE Wilson, G Rorrer [6]. In local ethanol recovering pipes are buried in the water swamps to recover ethanol as the distillate, in petro chemicals and petroleum industries, heat exchangers - chillers are used to enable the change of state - gaseous state to liquid state. A.C. Yunus, and A.B., Michael [7]. The factors that could affect cooling efficiency are:

(i) Flow rate of the heat sink or velocity

(ii) Length/size of the cooling median

(iii) Surface area of the coolant and gas exposed

(iv) Ambient temperature of the coolant

(v) Turbulence of the flow of the cooling fluid

(vi) Material of the heat exchanger

Heat exchangers are of different types but heat transfer is by conduction and convection through direct contact and current movement respectively. The heat absorption of the flowing cooling water is a function of the flow velocity, length of tubes, and surface area exposed which is a determinant for the size of tubes used which houses and determined how exposed the surface area of gas or the hot fluid to be cooled.

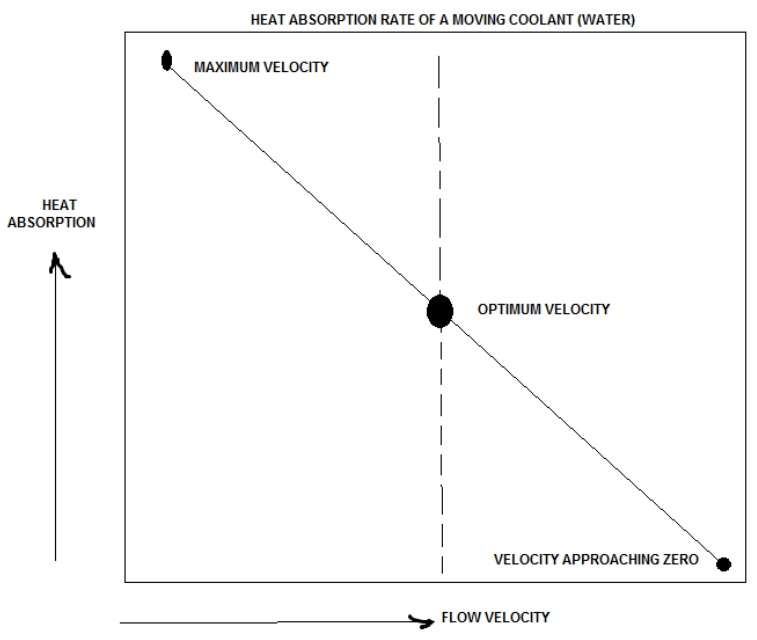

Fig: Heat absorption rate of coolant

\section{Description}

Condensers are designed and developed to allow cooling of products. They have exit and inlet parts for the cooling water (coolant) while the gaseous phase passes through the inner tubes. As basic description, condensers are designed to improved cooling efficiency hence the simple condensers, coiled condensers, double surface condenser, plate heat exchangers ,tube heat exchangers etc. The heat exchanger used in this work is the tube type with segmented baffles and impingement baffles. Baffles are use to slow down the flow of the heat sink (coolant) like water in this case and the impingement baffle creates vortexes or turbulence in the flow. However, some of the factors that affect the efficiency of heat exchangers have been outlined.

\section{Material Composition}

Material selection becomes relevant base of the environmental thermal and chemical conditions the product will be exposed. Hence stainless steel is selected for its resistance to corrosion, thermal shock, thermal conductivity and it weldability for easy fabrication. Aluminum would have been preferred for thermal conductivity and diffusivity but the cost and cost of fabrication are limitations.

\section{Thermal Efficiency}

The Thermal efficiency of the condenser made from stainless steel tubing

$\frac{\text { Energy Output }}{\text { Heat Energy }} \times 100 \%$

Heat Energy of the Steam

$\mathrm{Q}_{\mathrm{S}}=\mathrm{M}_{\mathrm{W}} \mathrm{C}_{\mathrm{W}}(\Delta \mathrm{T})+\mathrm{M}_{\mathrm{W}} \mathrm{L}_{\mathrm{W}} \quad 10$

This comprises the heat require to raise the water to $100^{\circ} \mathrm{c}$ and the heat of vaporization.

Heat absorbed by cooling water. H John. V. A Lienhard [8]

$\mathrm{Q}_{\mathrm{W}}=\mathrm{M}_{\mathrm{W}} \mathrm{C}_{\mathrm{W}}(\Delta \mathrm{T})$

$\Delta \mathrm{T}=$ temperature difference 
$\mathrm{C}_{\mathrm{w}}=$ specific capacity of water, $\mathrm{kj} / \mathrm{kg} 1{ }^{0} \mathrm{C}$

$\mathrm{M}_{\mathrm{w}}=\rho \mathrm{V}$

$\mathrm{M}_{\mathrm{w}}=$ mass of water

$\rho=$ desity of water, $\mathrm{Kg} / \mathrm{m}^{3}$

$\mathrm{V}=$ Volume of water in the condenser at a particular time $\mathrm{m}^{3}$

This comprises volume of water in the outer jacket to the gas conducting tube. Neglecting the heat lost to the surroundings through the Steel walls.

\section{Cooling Efficiency, $\eta_{\mathrm{c}}$}

The cooling efficiency is determined by the ratio of difference in temperature of the distillate to the temperature difference of the coolant. This is simply;

$\eta_{C}=\frac{\Delta\left(\mathrm{T}_{1}-\mathrm{T}_{2}\right)}{\Delta\left(\mathrm{T}_{3}-25\right)}$

11

As this depicts the ratio of work out put to work input, it determined from the slopes of the last two graphs difference in temperatures of distillate and coolant respectively.

\section{Model}

The models shown constitute the major components of the extraction machine.

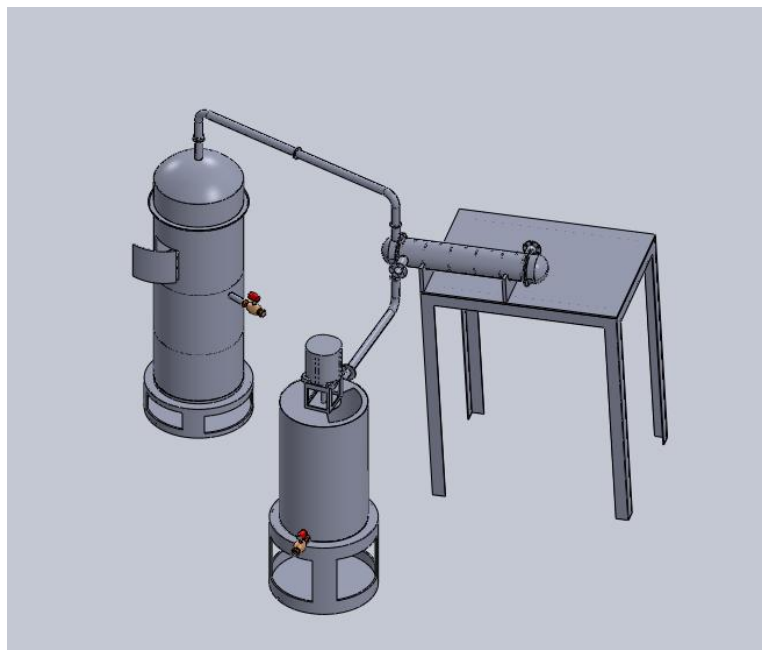

Fig: 3-D model of extraction plant

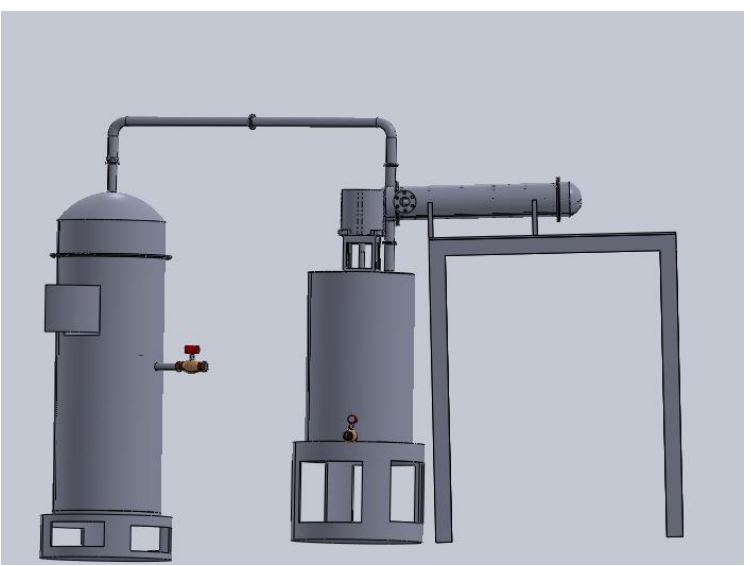

Fig: 3-D model of extraction plant

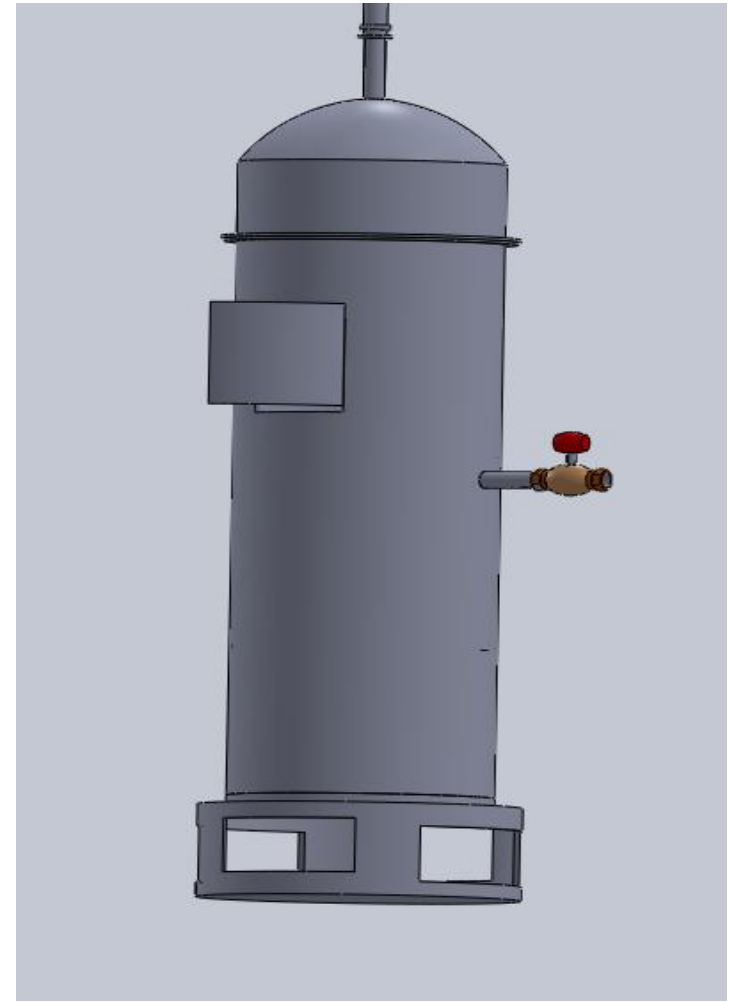

Fig: 3-D model of boiler

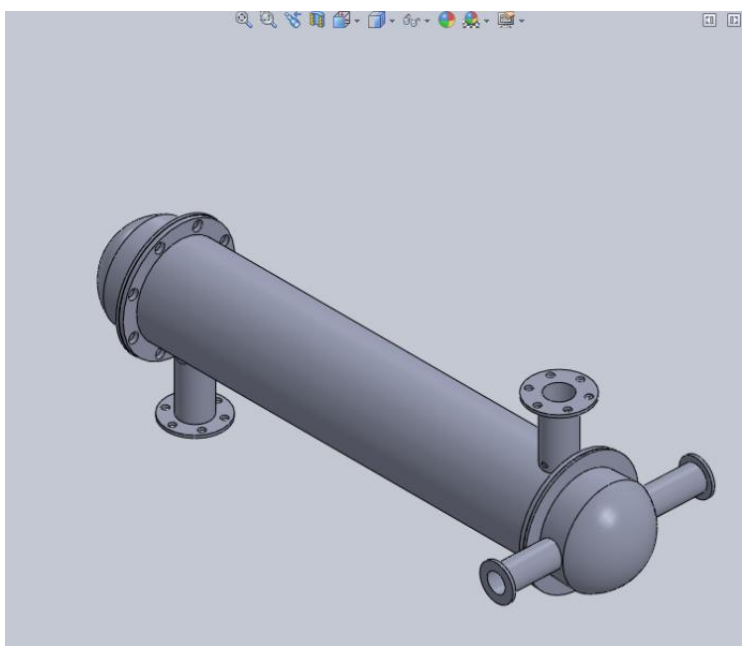

Fig: Heat exchanger

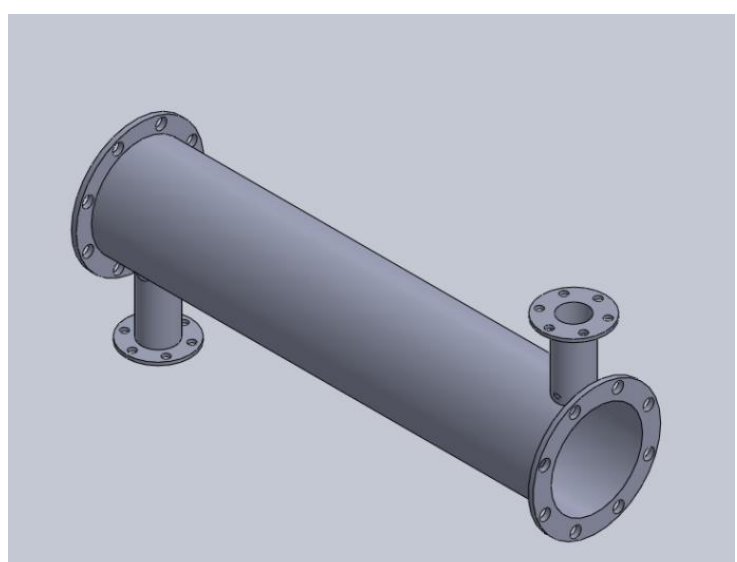

Fig: 3-D model of Heat exchanger Shell 


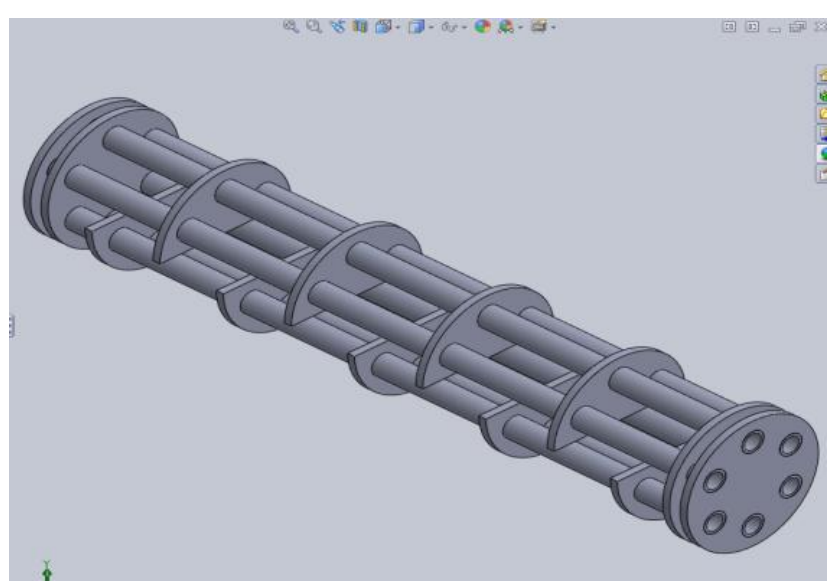

Fig: 3-D model of Heat exchanger tubes with baffles

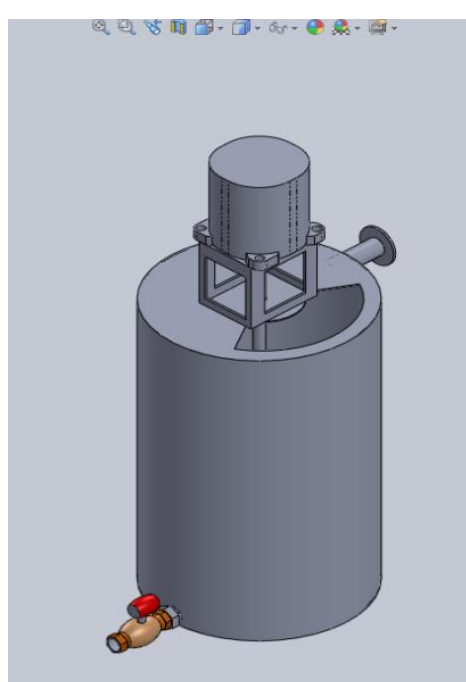

Fig: 3-D Model of the mixer

\section{APPENDIX}

This has the dimensions mm of the major components
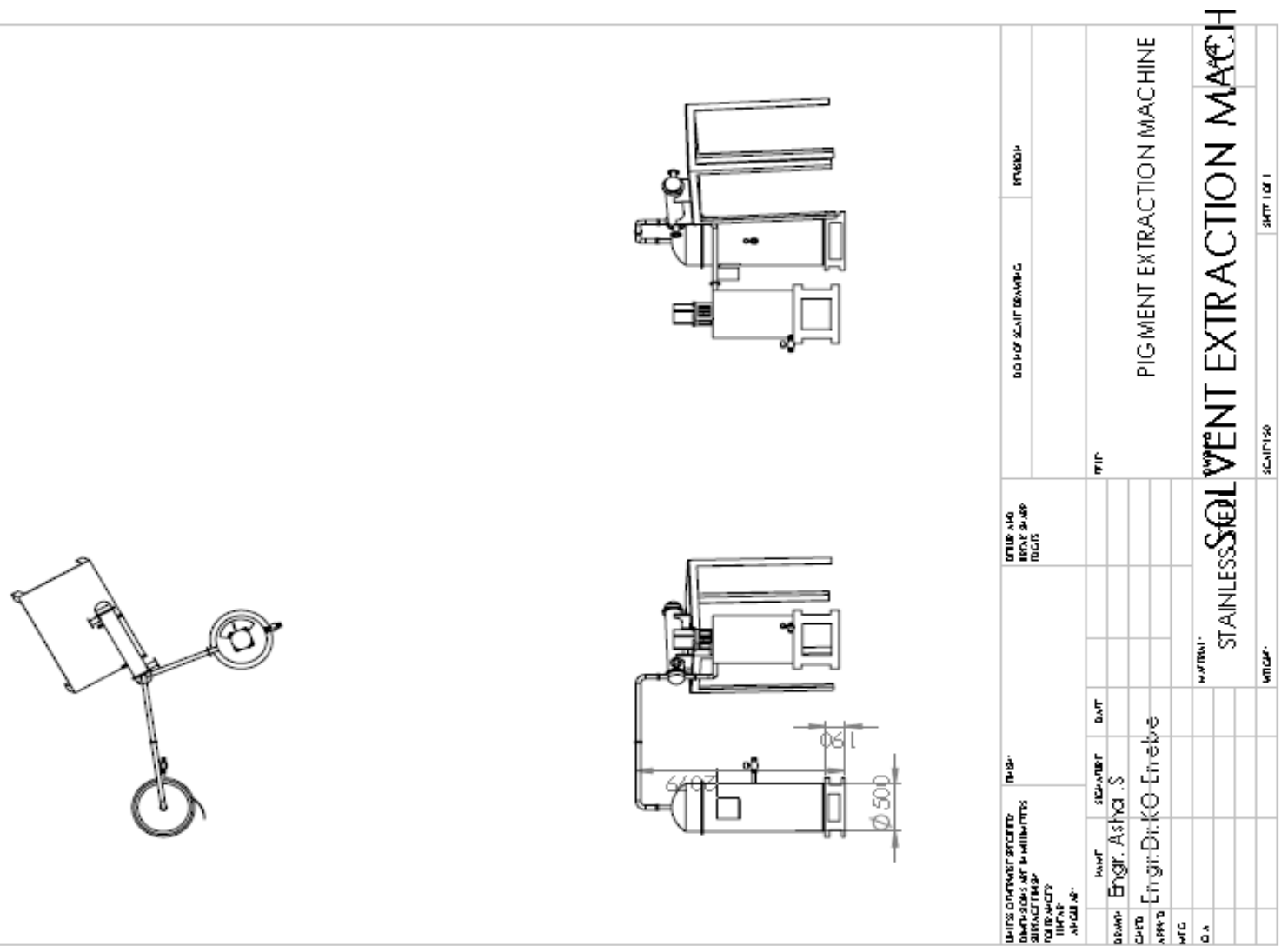

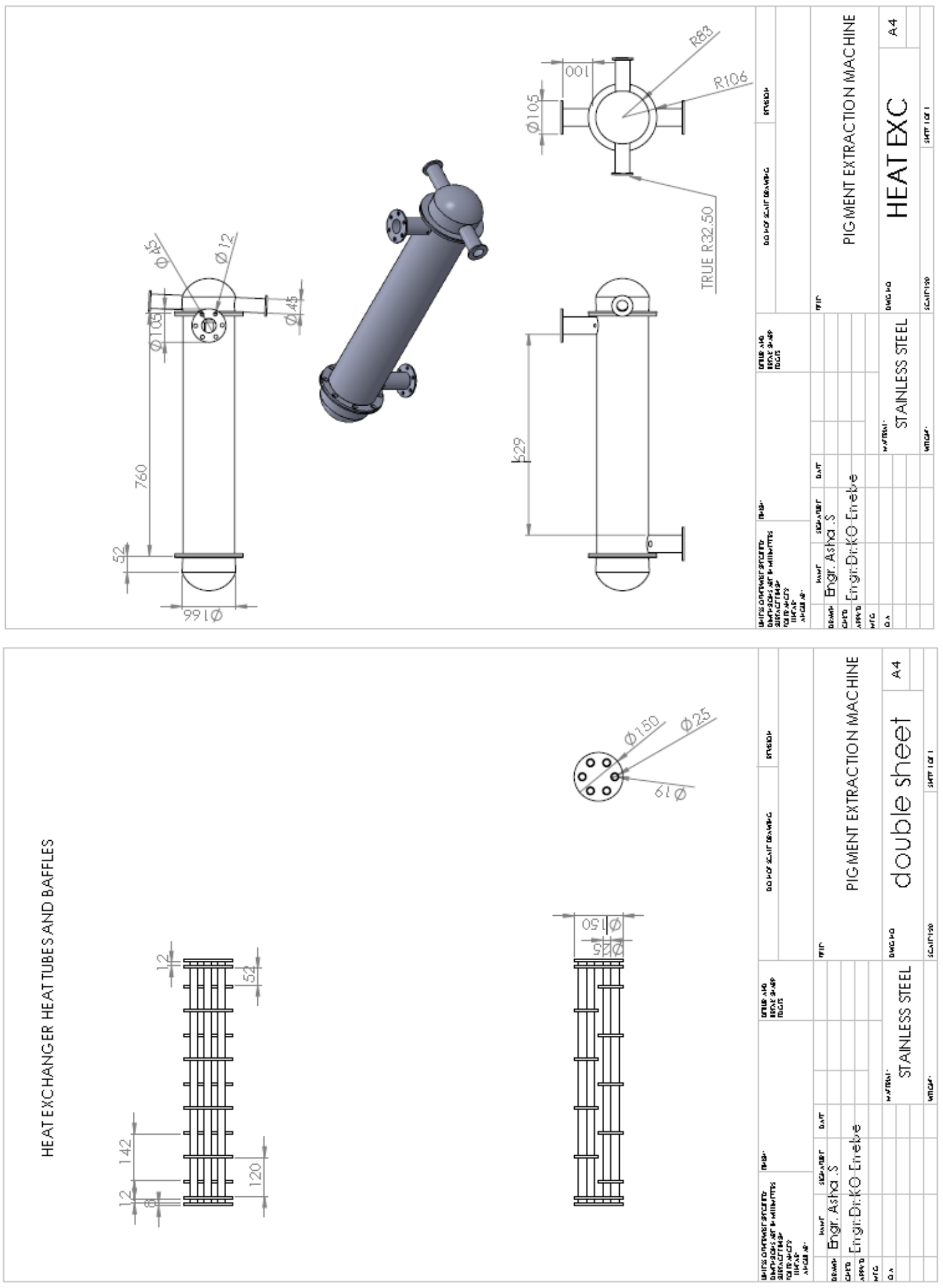

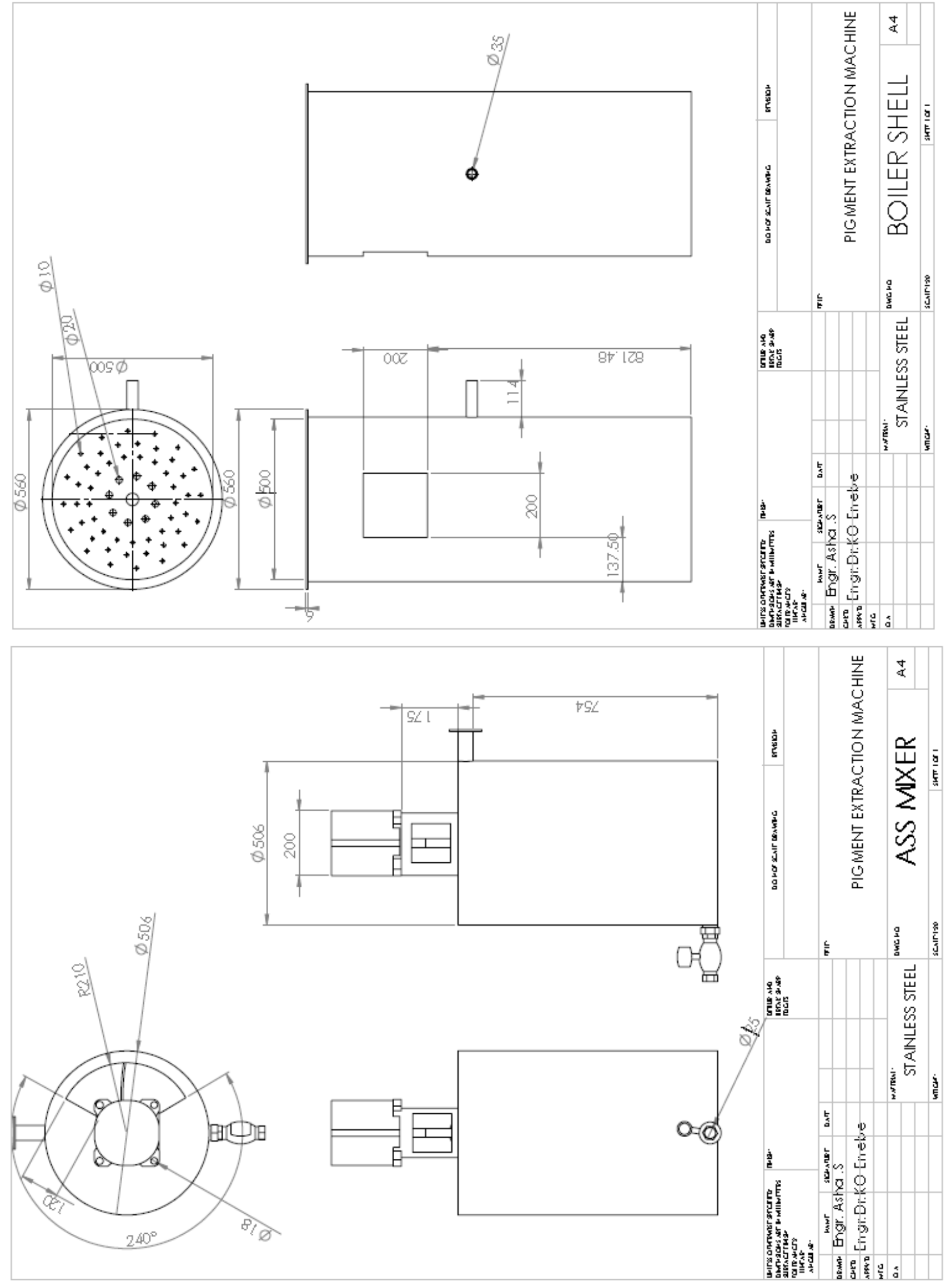


\section{CONCLUSION AND RECOMMENDATION Conclusion}

The machine is design with energy capacity $2030038.8 \mathrm{kj}$. The design of other components like heat exchanger is developed for the vapour content recovery of the product. Material selection was done based on hygiene and corrosion. Major component are shown and the appendix clearly shows their dimension in millimeters $(\mathrm{mm})$. The extraction machine can be use for production of local beverages, pharmaceutical industries and herbal medicine.

\section{Recommendation}

It is recommended that this design should be fabricated and performance evaluation be analyzed to aid improvement.

\section{REFERENCES}

1. Osueke JC, Ehirim FN. Chemical, Nutritional and Sensory Analysis of Zobo Drink (Var Sabdariffa) and Selected Soft Drinks, Journal of Agriculture and Food Science. April 2004; 2(1).
2. Pursoglove TW. Tropical Crops (Dicotyledons) Longman Pub. Ltd. Singapore. 1981; 370-374

3. Al-Nasser AA, El-Shabrawy Aboul-Enein M, AlAska AK. Systemic Lupus Erythematosus in Riyadh, Saudi Arabia. Journal of the Royal Society of Health. 1988 Jun;108(3):90-3.

4. Patankar SV, Spalding DB. A calculation procedure for heat, mass and momentum transfer in three-dimensional parabolic flows, Int $\mathbf{J}$ Heat Mass Transfer. 1972; 15:1787-1806.

5. Incropera FP, De Witt DP. Fundamental of heat and mass transfer, John Wiley \& sons. 1990.

6. Welty JR, Wicks CE, Wilson RE, Rorrer G. Fundamentals of momentum, heat, and mass transfer. USA: John Wiley \& Sons Inc.; 2000. 500e589288e326.

7. Yunus AC, Michael AB. Thermodynamics: An Engineering Approach, Singapore. 1989.

8. John H, Lienhard VA. Heat transfer textbook, Cambridge, Massachusetts: Phlogiston Press, pp. 352. CIBSE guide B2, ventilation and air conditioning. Norwich, UK: Page Bros (Norwich) Ltd.; 2001. 